\title{
'O INTRINCADO TORTO LIRISMO' DE AFONSO HENRIQUES NETO
}

\section{'THE INTRICATE BENT LYRICISM' OF AFONSO HENRIQUES NETO}

\author{
Marleide Anchieta de LIMA $^{7}$
}

\begin{abstract}
RESUMO: Este trabalho pretende analisar as peculiaridades líricas da poesia de Afonso Henriques Neto, situando-as no atual panorama literário brasileiro a partir de perspectiva que valoriza a noção de textualidade híbrida. Procura-se discutir os deslocamentos verbovisuais observados através de suas práticas formais e temáticas, na problematização de sua herança poética, seja em relação à geração "marginal", seja com os poetas da modernidade lírica, especificamente Rimbaud e Baudelaire.
\end{abstract}

PALAVRAS-CHAVE: Poesia brasileira contemporânea; Afonso Henriques Neto; Lirismo; Hibridismo.

ABSTRACT: This study aims to examine the peculiarities of the poetry of Afonso Henriques Neto, placing them in the current Brazilian literary scene from the perspective that values the concept of hybrid textuality. We will discuss the visual-word shifts observed through their formal and thematical practices, in the questioning of his poetic heritage, either in relation to "marginal" generation, either with the poets of the lyric modernity, specifically Rimbaud and Baudelaire.

KEYWORDS: Brazilian contemporary poetry; Afonso Henriques Neto; Lyricism; Hybridity.

Sem dúvida, a atualidade evidencia uma forte produção criativa no panorama literário brasileiro, sobretudo no âmbito da poesia. Cada vez mais, deparamo-nos com o jogo dialógico entre autores, tempos e espaços, além da articulação da poesia com outras expressões artísticas. Mas, observando o que a crítica Heloísa Buarque de Hollanda comenta: "a produção poética contemporânea [brasileira] se mostra como uma confluência de formas e temáticas sem estilos ou referências definidas" (HOLLANDA,

\footnotetext{
${ }^{7}$ Doutoranda em Literatura Comparada (Bolsista CNPq). Programa de Pós-Graduação em Estudos de Literatura. Instituto de Letras - Universidade Federal Fluminense (UFF) - Niterói - RJ - CEP 24210-201 -Brasil-_marlady@uol.com.br
} 
1998, p.11), elegemos para este ensaio alguma poesia de Afonso Henriques Neto ${ }^{8}$, poeta mineiro, peculiar por seus deslocamentos verbo-visuais, por suas oscilações formais e temáticas, assim como pela dificuldade de situá-lo em movimentos ou tendências específicas.

O trabalho do referido poeta rompe expectativas, desencadeia uma tendência à pluralidade discursiva, pois sua poesia solicita, constantemente, o diálogo e a abertura, num movimento de se desterritorializar e atualizar suas experiências espácio-temporais.

Essa perspectiva dinâmica da poesia remete-nos aos comentários de Maria Esther Maciel, no artigo "Escritas híbridas na poesia brasileira dos anos 70 e 80", que aponta o exercício de hibridismo na escrita como algo "que se abre aos influxos de várias formas, formatos e linguagens" e que tem sido, de certo modo, uma das marcas das últimas décadas (MACIEL, 2007, p.246). Entretanto, tal exercício não era visto sob essa perspectiva. O conceito de híbrido reuniu significados diferentes ao longo do tempo. Ele se originou, entre os séculos XVIII e XIX, nos estudos de Biologia, restringindo-se às propostas científicas de misturas das espécies. Posteriormente, sobretudo no século XIX, foi muito trabalhado pela Teoria Racial que tentava explicar a noção de mestiçagem, no início, compreendida como "mistura impura" (PAGANO; MAGALHÃES, 2005, p.2). Mais adiante, adquiriu um valor positivo através das transformações sócio-culturais e da visão dos pesquisadores cada vez mais atenta às relações inter-raciais, conforme assegura o crítico americano Robert Young (YOUNG, 1995, p.6). Com o decorrer dos anos, o conceito estendeu-se para outras áreas, como a Linguística, a Teoria Cultural e os estudos pós-colonialistas.

De acordo com Robert Young, "não há um conceito único, ou correto, de hibridismo" (YOUNG, 1995, p.6), mas o que se percebe é que não se trata de uma mistura em termos de fusão. Há a relação, concomitantemente, dialógica e antagônica entre dois elementos diferentes, estabelecendo-se um terceiro no qual os traços dos dois primeiros não são anulados, mas tensionados na ideia de múltiplo, heterogêneo, diverso e, para alguns pensadores, de anômalo e de irregular. Ou seja, o conceito de híbrido

\footnotetext{
${ }^{8}$ Afonso Henriques Neto iniciou sua trajetória poética com a publicação de $O$ misterioso ladrão de Tenerife, em 1972. Esse livro foi um dos primeiros produzidos num circuito que ficou conhecido como "geração marginal", principalmente pelo caráter independente e artesanal de sua edição. Além do diálogo com essa geração, o poeta apresenta uma privilegiada genealogia literária - é sobrinho-neto de Bernardo Guimarães, neto de Alphonsus de Guimaraens e filho de Alphonsus de Guimaraens Filho -, além da afinidade com os poetas da modernidade francesa (Baudelaire, Rimbaud e Mallarmé).
} 
abarca a ideia de heterogeneidade e pluralidade. Não há dúvida de que essa mobilização conceitual constituiu-se um passo importante para a existência de um hibridismo estético.

Segundo Maria Esther Maciel, a partir do final do século XX, diante da expansão e pluralização de dicções nos vários âmbitos do saber, "a palavra híbrido tornou-se um adjetivo recorrente também no campo cultural, não são poucos os poetas que têm buscado em outras modalidades discursivas modelos para a construção do poema" (MACIEL, 2006, p.105). A autora afirma que, no Brasil, isso se dá a ver de modo mais intenso e inventivo com a poesia dos anos 70, após o investimento em outras experiências, longe da linearidade e homogeneidade. Embora considere que já nos anos 60 a poesia concreta propunha uma prática híbrida, foi na década de 70 que, segundo ela, as mesclas textuais buscavam outras referências "para além da materialidade da linguagem e do experimentalismo formal" (MACIEL, 2007, p.247). Desse modo, Maria Esther defende que a prática de hibridismo poético adquiriu, nesse período, matizes diferentes, haja vista as preocupações dos poetas ao inserir na escrita o contexto político, a explícita presença da subjetividade e as inscrições do corpo no poema de forma mais veemente.

No que se refere à poesia de Afonso Henriques Neto, essa hibridização discursiva dos anos 70 faz-se visível pelo caráter heterogêneo de sua obra e pelas tensões que produz. Como é perceptível, o emaranhado de forças poéticas que constitui a escrita deste autor é composto pelos mais variados e flutuantes fios que indicam uma proposta lírica bastante peculiar. O presente e o passado, o referencial e o surreal, o coloquial e o erudito, a contenção e o excesso aparecem na poética de Afonso Henriques de modo intrincado. A convivência com os poetas da geração intitulada "marginal" e com a genealogia dos Guimaraens foi relevante na produção de formas alternativas e diversificadas para sua poesia. Além disso, vale lembrar o caráter significativo de sua filiação literária aos importantes nomes da lírica moderna, entre os quais se destacam Baudelaire, Mallarmé e Rimbaud - o trabalho deste, por sua vez, com sua intensidade, sua força visionária e vertiginosa, certamente foi o que deixou traços mais visíveis na escrita do poeta brasileiro. No poema "la mer mêlée au soleil", por exemplo, editado em Avenida Eros, de 1992, Afonso Henriques o intitula com versos rimbaudianos de "Elle est retrouvée!/ Quoi? L'éternité./ C'est la mer mêlée/ Au soleil." 
(RIMBAUD, 1999, p.197) - "Reencontrada é verdade!/ Quem? A eternidade./ É o mar que arde/ Com o sol." (tradução de Afonso Henriques Neto, 2009, p.97). Os traços do poeta francês são perceptíveis neste fragmento do mesmo poema:

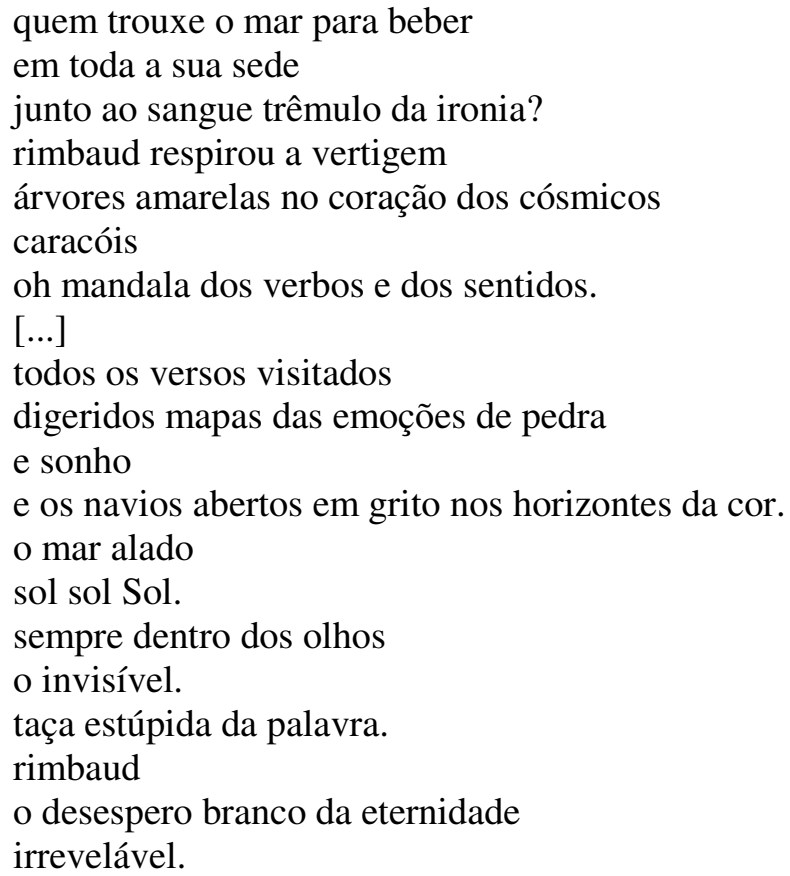

(HENRIQUES NETO, 2001, p.136)

Afonso Henriques insere-se na "mandala dos verbos e dos sentidos" do Simbolismo francês e desloca-se na linguagem do mar embriagado nos versos de Rimbaud - "quem trouxe o mar para beber/ em toda a sua sede/ junto ao sangue trêmulo da ironia?" (HENRIQUES NETO, 2001, p.136). Os lexemas "visitados" e "digeridos", encontrados no poema, expressam o encontro com o discurso do outro, produzindo, através da palavra, o desregramento sensorial e a presença onírica das imagens do "mar alado" misturado ao sol, o que é sugerido pelas expressões "sangue trêmulo", "respirou a vertigem", "cósmicos caracóis" e "desespero branco". A força visionária, a existência selvagem e desesperada e a expressão intensa rimbaudiana são sugeridas nos versos do poeta brasileiro: "sempre dentro dos olhos/ o invisível", "taça estúpida da palavra" e "desespero branco da eternidade/ irrevelável". Desse modo, nota-se que as marcas sinestésicas e o ritmo musical da escrita poética de Rimbaud deixam traços simbolistas no poema de Afonso Henriques Neto. 
Contudo, deve-se reconhecer que o Simbolismo na França, talvez mais do que aquele desenvolvido no Brasil, tenha deixado maiores marcas na poesia do autor mineiro. Nomes como Baudelaire, Mallarmé, Verlaine e Rimbaud movimentaram a literatura francesa no século XIX, construindo concepções acerca da arte que culminariam no movimento simbolista. Este último poeta, de acordo com Anna Balakian, em O Simbolismo, relaciona-se ao grupo apenas como um "parente por afinidade", pois sua obra apresenta um caráter bastante diferente, algo que revisava o “inconsciente e o estado onírico" proposto pela estética romântica ${ }^{9}$ (BALAKIAN, 2007, p.50) e dava "prioridade ao visual em lugar dos apelos musicais" (BALAKIAN, 2007, p.58), questões que seriam valorizadas pelos surrealistas no século XX. Acerca das singularidades rimbaudianas, registra a autora:

Ele saúda as possibilidades poéticas inerentes ao distúrbio e à turbulência dos sentidos que Baudelaire descrevera em seus relatos sobre o haxixe e vai mais além ao sugerir que o poeta, ao cultivar seus recursos interiores, deve perturbar conscientemente os sentidos (BALAKIAN, 2007, p.50).

De toda forma, inserindo-se ou não no Simbolismo, os "distúrbios e a turbulência dos sentidos" resultantes da alucinação verbal de Rimbaud são absorvidos por Afonso Henriques. Do mesmo modo, o poeta resgata o que considera mais precioso nesses autores franceses: seja a inserção do sórdido, do tom decadente, da preocupação com o gouffre (o abismo) nos poemas de Baudelaire; sejam a inquietude psicológica e saturnina, as sugestões sensoriais e a hipnótica musicalidade de Verlaine; seja o aspecto visionário, explosivo e selvagem dos versos de Rimbaud; sejam as fases mística, hermética e fragmentária do trabalho de Mallarmé. Afonso Henriques prioriza essa face maldita, a musicalidade, a sensibilidade e a rejeição à crença eufórica no progresso,

\footnotetext{
${ }^{9}$ Anna Balakian ressalta que o Romantismo encontrava no sonho "o estágio intermediário entre este mundo e o futuro" (BALAKIAN, 2007, p.20). O estado onírico permitia ao poeta romântico aspirar "ao infinito", ainda que, para isso, necessitasse almejar a morte. Para a autora, Rimbaud contrapunha esta visão, já que acreditava que o infinito e outras imagens poderiam ser criados pela linguagem, inventados com seu tom ébrio. A morte, para o poeta, é um "delírio aqui na terra", torna-se uma "realidade concreta da alucinação física" verbalmente expressa (BALAKIAN, 2007, p.58). Conforme apresenta a autora, Rimbaud não era adepto de aposentos fechados, escuros e com ar rarefeito, como acontecia com alguns românticos e simbolistas. Ele "buscava os alvoreceres brilhantes em vez dos crepusculares; não se refugiava em interiores escuros, mesmo no meio de sua crise espiritual" (BALAKIAN, 2007, p.58). O sonho era para ele um meio de concretizar a explosão artística.
} 
marcas desenvolvidas por esses poetas. No que tange ao Simbolismo brasileiro, o autor capta a fluidez da linguagem através dos recursos sonoros e cromáticos, o verbalismo requintado, o interesse pelo abismamento, pela morte e pelo enigmático, mas se afasta da espiritualidade excessiva desenvolvida nesse território. Aliás, os autores franceses, inseridos nesse grupo, rejeitavam a religiosidade vivida pela sociedade burguesa. Eles propunham uma religião da palavra, uma vez que almejavam explorar as suas potencialidades expressivas. Por outro lado, no Brasil, desenvolveu-se uma poética mística e quase litúrgica, com referências às orações, ao corpo morto, à busca metafísica. Como afirma o crítico Álvaro Cardoso Gomes, nosso Simbolismo "foi a mescla de altos anseios espirituais com uma forte sensualidade" (GOMES, 1994, p.50).

Como se observa, não há dúvidas da relação de Afonso Henriques com alguns poetas franceses, sobretudo Arthur Rimbaud, pelo seu caráter desterritorializado no movimento, assim como por sua poética idiossincrásica. Por isso, tanto o derramamento verbal, o inacabado, quanto a contenção e a brevidade, associados ao tom ébrio rimbaudiano demonstram a vitalidade de sua escrita e seu caráter oscilante. Embora o excesso de palavras seja um dos traços marcantes de seu estilo, assim como a veloz marcação rítmica, há momentos em que, na poesia de Afonso Henriques, aparecem experimentalismos poéticos próximos às inovações tipográficas dos concretistas; em outros, surgem versos mais breves, marcados pela rima e pela metrificação. A mescla de gêneros e formas é evidente em todas as obras do poeta, combinando a poesia com a narratividade, o ensaísmo, o texto performático da arte teatral e os roteiros cinematográficos.

Num longo poema sem título inserido no livro Cidade vertigem (2005), percebem-se algumas estratégias a construir o lirismo do poeta. Estas dão formas às associações espontâneas, ao jorro linguístico, à força verbal para compor o poema em prosa. Atesta-se essa intensidade discursiva no seguinte trecho:

prazer intenso caminhar pela cidade: fluir da manhã à noite, a pé, de ônibus metrô automóvel, não importa o meio, mas conhecer ao acaso os caminhos, construí-los de prazer, delícia, obsessão, dormindo em pequenos hotéis esquecidos em ruas perdidas no emaranhado, recomeçando no dia seguinte no centro da nebulosa amnésia, e reinventar o sol e a lua a queimarem os céus, nos vidros, nas fachadas, nos delírios urbanos, mapa aberto de cores e chuvas e ventos labirínticos nunca decifrados, amar a cidade no brilho e no óleo, 
intoxicar-se de vertigem, ser absolutamente moderno? mais-quecontemporâneo? saber ser irônico na hora certa, incorreta? Piadinhas intertextuais na ponta da língua? performar as tripas concretas o avesso do poema sucesso antologizado nos arraiais intelectuais de toda tribo? nada disso, nenhuma dessas asneiras ou dessas hipérboles. se transformar na cidade, metamorfose suprema. prazer total em ser cidade: retomar o flâneur baudelairiano, o andarilho urbano, o curtidor efêmero, o vagabundo consciente, o lascivo do instante, e ir além, e mergulhar no ritmo das formas e sons, perder-se nas cores, nos corpos, sair desenhando com a imaginação a infinidade de semblantes da correnteza humana [...]. (HENRIQUES, NETO, 2005, p.94).

O texto em análise assinala a ausência de fixidez e a possibilidade de movimentar prosa e poesia no mesmo espaço escritural. Segundo Andrea Catrópa, na dissertação Das margens ao infinito - a trajetória poética de Afonso Henriques Neto, o estilo de Afonso Henriques pressupõe "um híbrido de um gênero já metamórfico" (CÁTROPA, 2007, p.55), pois percorre tanto os traços narrativos e descritivos próprios da prosa quanto a expressão e o ritmo poético. Com isso, ele se propõe à tarefa de desestabilizar certezas e limites, seguindo a herança deixada por Charles Baudelaire, autor de Petits poèmes en prose, que, como aparentes minicontos, na verdade inauguram um outro gênero - o poema em prosa. Este, por sua vez, não abre mão do ritmo e da musicalidade presentes no poema, embora seja escrito formalmente com a mesma espacialização da prosa.

Certamente, essas formas marcadas, ao longo dos séculos, por uma história de antinomias (prosa versus poesia), experimentaram os traços sintomáticos da dissolução dos gêneros, uma vez que se inscreveram, como afirma Dominique Combe ao se referir a esse dualismo histórico, sob o "signo da impureza" (COMBE, 1989, p.108). Assim, não se torna gratuito o fato de Baudelaire, diante das aporias modernas, não se restringir à poesia pura, mas se expandir em direção ao registro considerado "impuro", ao fragmentário, ao novo ritmo inconcluso e pouco versificado da sociedade. Em "Spleen de Paris", o poeta aconselha o leitor a se relacionar com sua nova forma de poesia: "Lacere-a em diversos fragmentos, e verá que cada um deles pode existir à parte" (BAUDELAIRE, 2007, p.33). Em outro momento do mesmo poema, ele continua:

Quem dentre nós não sonhou, nos seus dias de ambição, com o milagre de uma prosa poética, musical sem ritmo e sem rima, flexível 
e desencontrada o bastante para adaptar-se aos movimentos líricos da alma, às ondulações do devaneio, aos sobressaltos da consciência? É sobretudo da frequentação das cidades enormes, é do cruzamento de suas inumeráveis relações que nasce este ideal obcecante. Você mesmo, meu caro amigo, não tentou traduzir numa canção o grito estridente do vidraceiro, e expressar numa prosa lírica todas as aflitivas sugestões que este grito envia até as águas-furtadas, através das mais altas brumas da rua? (BAUDELAIRE, 2007, p. 35).

A "frequentação das cidades enormes" e o "cruzamento de suas inumeráveis relações" parecem traduzir, por meio do poema em prosa baudelairiano, o sentimento da desordem e dos sentidos estilhaçados da modernidade. Desse modo, ao se valer dos procedimentos de ruptura implantados por uma tradição moderna de poesia, Afonso Henriques, no longo poema de Cidade vertigem, retoma a proposta do poeta francês de pensar o lirismo também no espaço citadino, prosaico e caótico. O texto é constituído com ritmo acelerado e similar ao da cidade, mas que se fragmenta com a constante marcação de vírgulas, colaborando com a expressão das vertigens e fugacidades da fraturada realidade urbana. O emprego dos verbos "caminhar", "fluir", "conhecer", “construí-los", "reinventar", "intoxicar-se", "performar", "se transformar", "retomar", “ir", "mergulhar", "perder-se" e "sair", além de oferecer mobilidade semântica ao poema, parecem confirmar a proposta lírica de Afonso Henriques, marcada pelo movimento, pela construção, reinvenção e retomada de tempos, espaços e discursos.

O gesto deambulatório é sugerido em toda organização textual; seja pelas escolhas lexicais - "ônibus metrô automóvel”, "ruas perdidas", “mapa aberto", "metamorfose suprema" -; seja pelo olhar que resgata a flânerie baudelairiana "perder-se nas cores, nos corpos [...]". O poeta visita questões relevantes para a modernidade lírica, dentre as quais não se destacam apenas a fragilidade demarcatória entre prosa e poesia, mas o resgate da figura do flâneur, o "andarilho urbano", o "curtidor do efêmero", que, de alguma forma, propõe a simbiose entre o sujeito e a cidade - "se transformar na cidade. Metamorfose suprema" - ou pelo menos sugere o ato de encenar essa imbricação identitária - "performar as tripas concretas o avesso do poema $[\ldots] ”$.

A poesia de Baudelaire expõe a flânerie enquanto experiência do olhar e do andar diante do movimentado contexto urbano. Ele expressa esse olhar atento, sagaz, voltado para o seu tempo, para a cidade, para a multidão e o que é produzido por ela. 
Nas palavras de Baudelaire, o flâneur é o "observador apaixonado" que se desloca pelo numeroso, ondulante e fugidio (BAUDELAIRE, 1996, p.22). Para o poeta, flanar é "estar fora de casa, e contudo sentir-se em casa onde quer que se encontre; ver o mundo, estar no centro do mundo e permanecer oculto ao mundo" (BAUDELAIRE, 1996, p.22). A relação conflituosa de pertença ao citadino, o distanciamento crítico e o anonimato constituem os "pequenos prazeres desses espíritos independentes" (BAUDELAIRE, 1996, p.22), como ressalta o escritor francês. Acerca desse novo personagem, sintomático do crescimento da urbe moderna, escreve Walter Benjamin, na obra Charles Baudelaire: um lírico no auge do capitalismo:

Havia o transeunte, que se enfia na multidão, mas havia também o flâneur, que precisa de espaço livre e não quer perder sua privacidade. Ocioso, caminha como uma personalidade, protestando assim contra a divisão de trabalho que transforma as pessoas em especialistas. Protesta igualmente contra a sua industrialidade. (BENJAMIN, 1989, p.50)

Essa condição do flâneur é resgatada por Afonso Henriques que investe na capacidade movediça da visão ao focalizar as imagens que circulam na paisagem urbana - “[...] navalha negra, espelho de tripas podres, lixo empurrado para o buraco do cérebro, lá onde se entrin-chei-ram os últimos relâmpagos do invisível, nos muros da cidade, mais que em todas as TVs [...]" (HENRIQUES NETO, 2005, p.95). Contudo, essa experiência é reescrita, de modo que, diante da cidade e do ritmo acelerado do capitalismo, o sujeito experimente um olhar elegíaco, resultante do caos sugerido pelas imagens da "navalha negra", "tripas podres", "lixo empurrado", "buraco do cérebro".

A mobilização do olhar corrobora a posição do poeta como um flâneur contemporâneo, uma vez que absorve da flânerie baudelairiana a inserção no anonimato, na liberdade e no ritmo da grande cidade. Dessa forma, ao transportá-la para o caráter itinerante da linguagem, através do poema, capta o que pode se tornar visível, além da visualidade mais evidente do espaço urbano. No que concerne a essa questão, comenta Adauto Novaes no prefácio de Cidade vertigem (2005), intitulado "Labirintos do poeta": 
Sabemos que Afonso Henriques, flâneur contemporâneo, trabalhou vinte anos em um único poema [...]. Em sua peregrinação pelas cidades, tudo é possuído pela visão. Ou quase tudo, porque seus olhos são desatentos ao mundo tal como ele é. Voltam-se para objetos que a visão racional negligencia e que estão na iminência de desaparecer do mundo. Para realizar esta visão, foi preciso antes abandonar a racionalidade imposta nas grandes cidades, fugir dos itinerários estabelecidos, 'perder-se na floresta'. E este é o segredo do poemaolhar: desejar outra coisa além do que é dado a ver. (NOVAES, 2005, p. 8).

A flânerie de Afonso Henriques acontece também em suas escritas híbridas, pois o poeta deixa-se conduzir pela errância entre diferenciados gêneros discursivos. Se em suas obras transita pelos poemas em prosa, também a dimensão ensaística encontra espaço em seus projetos. O livro Cidade vertigem é um exemplo nítido desse hibridismo. Composto por linguagens múltiplas, entrelaça poesia, narrativa, ensaio e relatos de experiências vividas pelo autor. Sobre isso, explica o poeta: "Quando escrevia o poema da cidade já tudo se misturava, todas as indagações se fundiam como que para revelar a visão mais aberta do possível pulsante, imenso organismo que eu tentava capturar em todas as cores, ritmos, imagens, virulências, desatinos" (HENRIQUES NETO, 2005, p.161).

A busca da "visão mais aberta" distancia o poeta de quaisquer discursos de lirismo purista, já que não se recusa a se envolver com a "inevitável prosa do mundo" (INIMIGO RUMOR, 2003, p.4). O poeta objetiva a liberdade, montando textos, reescrevendo-os, dialogando com outros, recorrendo ao "itinerário de pensamentos" (NOVAES, 2005, p.9), à transitividade das palavras e às relações que elas estabelecem para gerar sentidos e imagens. É a errância pela linguagem que lhe permite frequentar todas as formas possíveis de registro literário e o conduzir à subversão dos binômios prosa/ poesia, lirismo/ narratividade, desestabilizando a própria concepção clássica de lírico. Adauto Novaes, no prefácio citado, chama a atenção do leitor para o ecletismo discursivo na obra de Afonso Henriques.

A construção é feita na linguagem, que é tomada não como um meio de expressão, mas como uma prática e uma experiência poética: a mistura de poesia e prosa poética neste caso é determinante. Ao recolher os vestígios da fala e dos acontecimentos, ao lidar com a prosa, quase sempre sujeita à facilidade muito linear, o autor apropria- 
se da linguagem ordinária, caminho possível para falar da cidade sem cair na armadilha da abstração e da 'arte pela arte'. Todo o livro é permeado pela tensão do desejo de preservar aquilo que pertence à poesia do poeta e a necessidade de revelar os enigmas da cidade. Esta ambiguidade do privado e do público é bem resolvida neste poema em prosa cuja virtude consiste não em exprimir algo mas sim no fazer. $\mathrm{O}$ resultado é uma outra prosa tão trabalhada como os versos. Impossível não notar a musicalidade, o ritmo e a sintaxe que modulam o texto. A fragmentação do itinerário e dos vestígios deixados pela cidade impõe condensações e rupturas ao texto, à maneira dos poemas. É isso que dá o sentido de uma poesia pensada, na qual cada palavra pode nos levar ao abismo [...]. (NOVAES, 2005, p.7-8).

Em Cidade vertigem, o autor, com olhar ativo para as tensões presentes no texto, consegue exercer uma postura reflexiva diante de seu trabalho. Jean-Michel Maulpoix, no livro Du lyrisme, explica que com a modernidade, a partir de Baudelaire, o poeta tornou-se um crítico de seu próprio fazer artístico, pois ele desenvolve um movimento de reflexão, mesmo que essa experiência não lhe pareça muito clara (MAULPOIX, 2000, p.100). Ora, Afonso Henriques, ainda que não se defina como um crítico literário, não deixou de experimentar os tons perquiridores da escrita ensaística. Observa-se nesse fragmento de "Psicomorfismos urbanos", inserido em Cidade vertigem, as marcas especulativas próprias do ensaio, nas quais o poeta tece considerações sobre as confluências entre psique, visão poetizada da cidade e o caos urbano:

Ao processo de conformação deste 'desenho' da cidade, nascido da personalidade literária dos autores, é que chamamos de psicomorfismo urbano. Ou seja, o modo peculiar e original - inerente a cada artista de revelar, a um só tempo, a surpresa de um cenário visível/ invisível, real e simbólico. Implacável cidade que, do fundo da sensibilidade poética, se desenhasse por sobre as linhas da cidade concreta, mito a construir-se sobre os claros contornos da realidade. Encontros mágicos entre autor e cidade, entre poíesis e kháos, entre ficção e forma arquitetônica, entre discurso literário e linguagem urbana. (HENRIQUES NETO, 2005, p.161).

É por esse viés que o poeta se envolve com o caráter especulativo do ensaio. Afonso Henriques, portanto, levanta hipóteses que lhe permitem introduzir a relação entre a poesia e a cidade. Assim, ele o faz com base nos questionamentos de Carlos Drummond de Andrade: "Em um repente voltou-me a voz de Carlos Drummond de Andrade: de que se formam os poemas?; e ainda agora, em estranha continuidade 
sonora, insiste em ressoar em mim refrão semelhante: 'com que material construímos a mágica do poema?’” (HENRIQUES NETO, 2005, p.160). E o poeta continua, mas se auto-especulando: "(maneira talvez enviesada de se tecer a indagação drummondiana)" (HENRIQUES NETO, 2005, p.160). Tal "maneira enviesada" constitui-se formas de registrar hipóteses, ainda que permaneçam sem respostas.

O crítico Theodor Adorno, em "O ensaio como forma", questiona: "Como seria possível, afinal, falar do estético de modo não estético, sem qualquer proximidade com o objeto [...]?” (ADORNO, 2003, p.18). A questão levantada por Adorno pressupõe pensar no discurso crítico que já não se impregna de dicotomias entre a abordagem objetiva e as impressões subjetivas, pondo em xeque as tradicionais fronteiras dos gêneros. Talvez, por isso, Afonso Henriques permita que sua subjetividade acione indagações - "Por um momento cheguei a acreditar que Brasília era enfim aquela pobre cidade de madeira e muita terra vermelha, algo assim nos moldes dos filmes sobre o oeste norte-americano" (HENRIQUES NETO, 2005, p.125) -, sem deixar de apostar na objetividade, frequentemente encontrada no texto ensaístico - "o poeta sabe que enquanto estiver lançando no vento seu protesto indignado, ou mesmo uma desesperada indiferença, ele estará mantendo a respiração do mundo da linguagem” (HENRIQUES NETO, 2005, p. 162).

Sendo assim, o poeta consegue intrincar a poesia e o ensaio e, de modo similar, propõe a circulação de várias tendências no mesmo espaço textual. Na Sequência 2 (Indefinido/ Improvável), do poema "meu coração experimental", cuja escrita aproxima poesia e roteiro cinematográfico, há o encontro de elementos referenciais, tais como "mendigos", "paredes do City Bank", "ruelas das favelas", "prédios públicos de Brasília", com ressonâncias de um lirismo simbolista. Tem-se aqui um fragmento do poema citado:

Corta para as cenas de miséria bem conhecidas: mendigos encostados nas paredes do City Bank, câmara nervosa percorrendo as ruelas das favelas, retirantes da seca, epidemia e violência contra os indígenas, Ceilândia x salões em festa nos prédios públicos de Brasília, subúrbios \& rios imundos, takes de multidão nos centros urbanos, nos campos de futebol, nos transportes de massa, etc. (imagens em explosão), enquanto no meio dos ruídos desencontrados e pedaços de óperas de discos arranhados surgem esses fiapos de frases: "meus olhos captam a luz mais pura... minha boca cospe o verbo do caminho perfeito... 
meus ouvidos reconhecem a melodia essencial... minhas mãos indicam as vertigens do futuro...” [...]. (HENRIQUES NETO, 2001, p.116-117).

As marcas lexicais da linguagem fílmica se fazem presente no poema - "corta", "câmara", "takes", "imagens em explosão" -, focalizando miséria, desordem e desigualdade como perfil sintomático dos centros urbanos do Distrito Federal. Tais sintomas que, com certa frequência, são explorados pelos meios de comunicação na tentativa de apresentar as circunstâncias através de uma textualidade denotativa, inserem-se na escrita poética de Afonso Henriques enquanto "imagens em explosão", com o intuito de percorrer os traços desordenados que compõem a paisagem citadina. Dessa forma, os "mendigos encostados nas paredes do City Bank", as "ruelas das favelas", os "retirantes da seca", a "epidemia e violência contra os indígenas", os "salões em festas nos prédios públicos de Brasília", os "subúrbios \& rios imundos", a multidão nas ruas e nos transportes são captados pelo olhar do poeta que compreende a atmosfera alarmante a se expandir pelas metrópoles.

Em meio ao caos urbano, em que se percebem "ruídos desencontrados", "pedaços de óperas de discos arranhados" e todo um contexto de dissonância, o poeta deixa ecoar os "fiapos de frases" da dicção simbolista - "meus olhos captam a luz mais pura... [...] meus ouvidos reconhecem a melodia essencial... minhas mãos indicam as vertigens do futuro...". Porém, sem desprezar o tom irônico que o mantém consciente da realidade que o circunda: "minha boca cospe o verbo do caminho perfeito...".

Se o Simbolismo privilegiava a evocação de "uma realidade situada além dos sentidos", como afirma Afrânio Coutinho (COUTINHO, 1986, p.322), Afonso Henriques, ainda que muitas vezes lance mão dessa realidade simbolista, não abdica da referencialidade do contexto no qual se insere e acredita na força verbal como forma de posicionamento ético frente ao mundo. Sobre isso, o poeta exprime comentário numa entrevista realizada por Andréa Catrópa: "Poesia é antes de tudo olhar o mundo pela ótica da ética e da solidariedade com tudo quanto vive e luta para brilhar ao sol. O verso sem essa cintilação profunda é tinta morta sobre o papel” (CATRÓPA, 2007, p.200).

A relação entre o poeta e o mundo corrobora o projeto de um lirismo intrincado, em que tanto o real quanto o onírico partilham espaços. Marcelo dos Santos, em Murmúrio da sombra: aspectos do noturno na poesia de Afonso Henriques Neto, 
ressalta que o poeta coaduna-se com um discurso em trânsito, preservando a mesma ambivalência que reside na palavra poética (SANTOS, 2006, p.58). É essa posição que lhe permite transfundir mundos distintos.

O que se mostraria contrário ao mundo e aos sentidos - o mundo dos sonhos -, o poeta parece, ainda, reconhecê-lo como intermediário, preferindo se equilibrar estrategicamente nessa margem onde transitam os indícios do mundo, do sentido e do não-sentido, curso no qual se engendram as químicas da palavra. (SANTOS, 2006, p.58).

Afonso Henriques extrai dos "indícios do mundo" a materialidade de sua poesia, de modo a articulá-la com o sonho, com o delírio e com a viagem que propiciam a explosão de imagens e sua relação com "as químicas da palavra". Nesse sentido, faz-se mister mencionar que é o arranjo musical, rítmico e imagético desencadeado na poesia que o torna próximo à prática simbolista, já que os seguidores dessa tendência literária investiam nas associações de ideias, nas impressões sensíveis sugeridas no processo poético. De modo similar, o tom caudaloso, as imagens desconexas e a força do onírico confirmam a presença de um veio surrealista em sua experiência híbrida.

De acordo com o poeta Cacaso, Afonso Henriques "pratica um surrealismo com sotaque... mineiro", já que "sua imaginação é aérea; sua síntese poética se dá num elevado grau de abstração" (CACASO apud HENRIQUES NETO, 2001, p.258). O "sotaque mineiro" demonstra uma aproximação com cautela e desconfiança entre a estética surrealista e a dicção livre do autor. Observa-se também, ao contrário do que defende Cacaso, que sua obra nem sempre chega à "síntese poética" ou a um "elevado grau de abstração", pois ela privilegia um trabalho de constante tensão provocada pelo próprio exercício híbrido: "se me adianto muito/ meu sumo é lírico aquoso/ se me atraso em excesso/ a sílaba se engasga de pedra/ em retard é medida esperta/ quase errada quando certa" (HENRIQUES NETO, 2001 p.206). É a fusão de elementos do real e do sonho, o entrelaçamento de ambos, que dá ao poeta não o rótulo de surrealista, mas a confirmação de tais procedimentos que se agregam na multiplicidade de discursos que constituem seu lirismo. 
Não se pode negar, portanto, a arrealidade ${ }^{10}$ que atinge as imagens produzidas por Afonso Henriques: "a palavra que costura o real/ esfiapou-se./ tarda a pedra no molde vazio./ onde era cinza/ inesperada frase de música." (HENRIQUES NETO, 1995, p.8). Talvez, por este motivo, Armando Freitas Filho aponte o poeta e Roberto Piva como pertencentes a um outro eixo poético, no qual fizeram parte dois importantes nomes da literatura brasileira, Jorge de Lima e Murilo Mendes (FREITAS FILHO, 1979, p.106), poetas de fortes marcas surrealistas. Dessa forma, Afonso Henriques integra-se a uma "linhagem noturna", cujos efeitos de obscuridade e de trabalho com os aspectos oníricos se deixam notar. É, nesse sentido, que ele traduz as palavras de Rimbaud, transportando-as para sua própria poesia: “O poeta é realmente um ladrão do fogo" (RIMBAUD apud HENRIQUES NETO, 2009, p.16).

O crítico Fábio Andrade, no livro $O$ engenheiro noturno, no qual desenvolve um estudo sobre o caráter órfico da poesia de Jorge de Lima, identifica marcas de uma dicção simbolista e surreal a inscrever a noite no poema, possibilitando ao poeta retomar os gestos de Orfeu que desceu ao mundo das sombras para entoar sua lira (ANDRADE, 1997, p.156). Assim, Afonso Henriques propõe-se a compartilhar desse gesto que reitera sua relação com a linguagem órfica de Murilo Mendes e Jorge de Lima, ao valorizar o que Fábio Andrade aponta como relevante na escrita do poeta alagoano: "a estética do sombrio, do feio, da loucura e da morte em dois movimentos em particular: o simbolismo francês em sua facção 'maldita' e os surrealistas" (ANDRADE, 1997, p.156): "pensamento a soabrir a pálpebra/ para fora da luz/ antiuniverso da matéria/ sem palavras. orfeu hidrofeu catastrândula./ entre os mortos/ e a congestão nasal/ passeia um sacerdote antiquíssimo/ e a sábia indiferença/ do abismo oval.” (HENRIQUES NETO, 2001, p.135).

Num jogo de luzes e sombras constroem-se os poemas, pois é por meio da tinta escura sobre o branco do papel que as ambivalências são sugeridas. Segundo Silviano Santiago, no livro intitulado Carlos Drummond de Andrade, ao contrário da criação divina que se projeta a partir da claridade, o procedimento humano, em suas articulações estéticas, ocorre em outra direção, uma vez que a tinta "de que se servem os homens é treva e escuridão, mas é só com ela que conseguem criar sobre o branco e o

\footnotetext{
${ }^{10}$ Raúl Antelo fala de arrealidade, baseando-se no conceito de Jean-Luc Nancy, que alude tanto à superfície, à área da pele de um corpo visto como um conjunto de sensores, quanto ao pouco ou quase nada de realidade material ou substantiva que constitui sua ausência (ANTELO, 2007, p.189).
} 
virginal da margem, no seu silêncio" (SANTIAGO, 1976, p.110). Afonso Henriques desenha com os traços negros da tinta os fragmentos, o derramamento verbal e imagético, o prosaísmo, de modo que a linguagem produza feixes luminosos de sentidos e o olhar perceba o fluxo contínuo que é sua escrita: "O texto, escura escama, pesadelo de eternidade,/ máscara densa do universo vomitando./ O texto, mas não a energia que o pensou,/ interrogando a simultaneidade absoluta" (HENRIQUES NETO, 2001, p.17). Nesse fragmento do poema "texto", publicado em O misterioso ladrão de Tenerife, a textualidade que é "escura escama", traz consigo a ambiguidade inerente ao ato poético, por isso se faz "máscara densa". Mas, a escrita também almeja "um texto além do texto" percebido por "olhos além/ da frágil realidade". Daí, o poeta lançar-se ao fluxo verbal e imagético.

A forte relação que Afonso Henriques estabelece com as imagens leva-o a enriquecer seu lirismo com a visita a outras práticas artísticas. Através dessa relação interartes, o poeta mobiliza seu olhar e experimenta os limites estéticos da visualidade, transpondo-os para a composição dos poemas. Desse modo, ele defende: "Não existe nada puro" (HENRIQUES NETO apud CATRÓPA, 2007, p.199); há sempre um trabalho permanente de articulações imagéticas e discursivas que abarca muitas linguagens e apresenta aberturas a outros diálogos.

Em tempos de escritas híbridas, Afonso Henriques confirma a ausência de pureza lírica. Ele aposta no hibridismo de formas e de discursos, desestabilizando fronteiras e reinventando estruturas. Nesse intrincado lirismo, o poeta tenta adentrar a linguagem com suas múltiplas instâncias, mas essa tentativa demonstra sua impossibilidade de dizer tudo e de todas as maneiras, pois o texto é uma busca, está sempre em formação, em processo de metamorfose. O próprio ato de reescrita sugere as lacunas linguísticas e suas dissoluções: "pensando bem/ nenhum ofício aprendi/ a não ser este de embaralhar palavras/ à procura de uma essência cada vez mais rara" (HENRIQUES NETO, 2001, p.224). É no ato de "embaralhar palavras" e de inventar imagens que o poeta expande sua escrita em direção ao outro, ao dinâmico e ao diverso e assume os riscos que, porventura, circunscrevam a liberdade de seu trabalho literário.

\section{REFERÊNCIAS}


ADORNO, Th. O ensaio como forma. In: Notas de literatura I. São Paulo: Ed. 34/Duas Cidades, 2003.

ANDRADE, F. de S. O engenheiro noturno. São Paulo: EDUSP, 1997.

ANTELO, R. La arealidad setentista. In: GARRAMUÑO, F. et al. Experiencia, cuerpo y subjetividades: literatura brasileña contemporanea. Rosario: Beatriz Viterbo, 2007.

BALAKIAN, A. O Simbolismo. São Paulo: Perspectiva, 2007.

BAUDELAIRE, C. O pintor da vida moderna. In: COELHO, T. (Org.). A modernidade de Baudelaire. Rio de Janeiro: Paz e Terra, 1996.

Pequenos poemas em prosa [O Spleen de Paris]. São Paulo: Hedra, 2007.

BENJAMIN, W. Charles Baudelaire - Um lírico no auge do capitalismo. São Paulo: Brasiliense, 1989.

CATRÓPA, A. Das margens ao infinito - a trajetória poética de Afonso Henriques Neto. 2007. Dissertação (Mestrado) Programa de Pós-Graduação em Teoria Literária e Literatura Comparada - FFLCH, Universidade de São Paulo, São Paulo, 2007.

COMBE, D. Poésie et récit, une rhétorique des genres. Paris: José Corti, 1989.

COUTINHO, A. A literatura no Brasil. 3.ed. Rio de Janeiro: José Olympio, 1986.

FREITAS FILHO, A. Poesia viva. In: NOVAES, A. (Org.). Anos 70 - ainda sob a tempestade. Rio de Janeiro: Aeroplano/SENAC, 2005.

GOMES, Á. C. O Simbolismo. São Paulo: Ática, 1994.

HENRIQUES NETO, A. Ser infinitas palavras (poemas escolhidos \& versos inéditos). Rio de Janeiro: Azougue, 2001.

Cidade vertigem. Rio de Janeiro: Azougue, 2005.

(Org. e trad.). Fogo alto: Catulo, Villon, Blake, Rimbaud, Huidobro, Lorca, Ginsberg. Rio de Janeiro: Azougue, 2009.

HOLLANDA, H. B. de. Esses poetas: uma antologia dos anos 90. Rio de Janeiro: Aeroplano, 1998.

INIMIGO RUMOR - Revista de Poesia. Rio de Janeiro: 7Letras, n.14, jan. 2003.

MACIEL, M. E. Travessias de gênero na poesia contemporânea. In: PEDROSA, C.; CAMARGO, M. L. de B. (Org.). Poéticas do olhar e outras leituras de poesia. Rio de Janeiro: 7Letras, 2006.

Escritas híbridas na poesia brasileira dos anos 70 e 80. In: GARRAMUÑO, F. et al. Experiência, cuerpo y subjetividades: literatura brasileña contemporanea. Rosario: Beatriz Viterbo, 2007.

MAULPOIX, J.-M. Du lyrisme. Paris: José Corti, 2000.

NOVAES, A. Labirintos do poeta. In: HENRIQUES NETO, A. Cidade vertigem. Rio de Janeiro: Azougue, 2005.

PAGANO, A.; MAGALHÃES, C. Análise crítica do discurso e teorias culturais: hibridismo necessário. DELTA: Documentação de Estudos em Linguística Teórica e Aplicada, São Paulo, v.21, 2005, p.7-27. 
RIMBAUD, A. Poésies. Une saison en enfer. Illuminations. Paris: Gallimard, 1999.

SANTIAGO, S. Carlos Drummond de Andrade. Petrópolis: Vozes, 1976.

SANTOS, M. dos. Murmúrio das sombras: aspecto do noturno na poesia de Afonso Henriques Neto. 2006. Dissertação (Mestrado em Literatura Brasileira) - Faculdade de Letras, Universidade do Estado do Rio de Janeiro (UFRJ), Rio de Janeiro, 2006.

YOUNG, R. J. C. Colonial desire: hybridity in theory, culture and race. London and New York: Routledge, 1995.

Artigo recebido em 09/04/2011

Aceito para publicação em 07/06/2011 